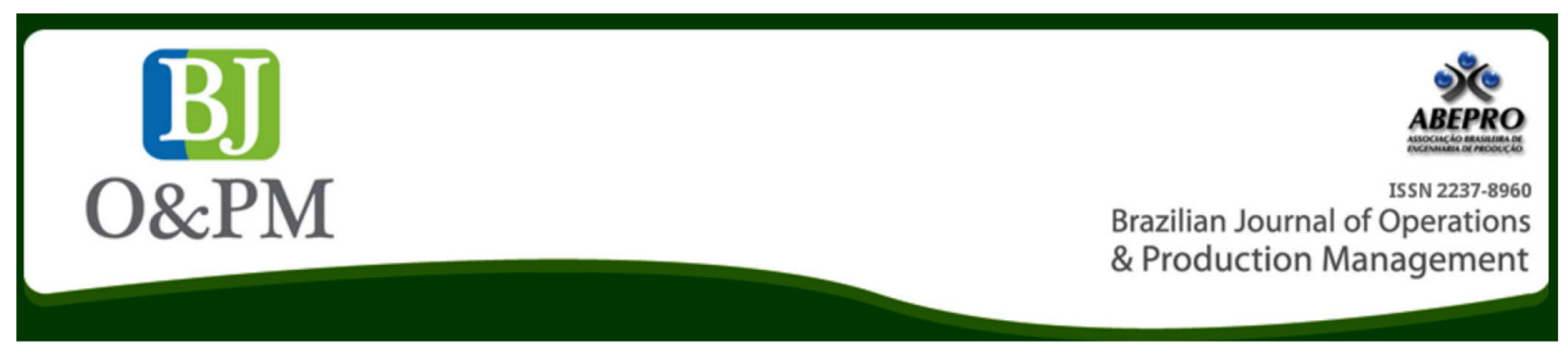

\title{
THE CURRENT CONTEXT OF LEAN AND SIX SIGMA LOGISTICS APPLICATIONS IN LITERATURE: A SYSTEMATIC REVIEW
}

\begin{abstract}
Edra Resende de Carvalho ${ }^{1}$, Ana Elaje Azevedo Simões da Mota ${ }^{1}$, Gabriela Maués de Souza Martins ${ }^{1}$, Leonardo dos Santos Lourenço Bastos², André Cristiano Silva Melo ${ }^{1}$
\end{abstract}

1 Pará State University - UEPA

2 Pontifical Catholic University of Rio de Janeiro - PUC-Rio

\begin{abstract}
Originated in the Toyota Production System, the concept of lean production has become widely disseminated and broadly applied in the industry. When considering lean and six sigma principles in logistics, companies have obtained advantages in terms of cost and quality, which encouraged scientific researches for improvements in the topic. To study the current state of the art on Lean Logistics (LL) and Six Sigma Logistics (SSL), in the national and international level, a systematic review of lean and six sigma logistics were performed, aiming to evaluate theoretical and practical applications, in order to classify the current literature and propose studies to address research opportunities. For this purpose, a review protocol was created to guide and structure the review. As results, it was identified that Transportation has been the main logistic operational drive component in which LL has being applied. The most frequent type of waste considered was Motion and most of the studies were practical applications. Finally, this study found considerable research opportunities for future studies.
\end{abstract}

Keywords: Systematic Review; Lean Manufacturing; Lean Logistics; Six Sigma. 


\section{INTRODUCTION}

Based on the Toyota Production System (TPS), Lean Manufacturing had its origin after World War II, when Toyota, in order to outstand from its competitors in terms of quality, reinvented the mass production model, focusing on eliminating time and material waste in its production process. Consequently, Toyota could obtain fast and flexible processes, allowing it to offer customers what they want, when they want it, with high quality and at a reasonable price (Liker, 2005).

In the economic context, companies have been searching for the development of continuous improvement habits, waste elimination and improvement of the skills in their human resources, and those practices were related to Lean thinking (Gonçales Filho et al., 2014). The concept of Lean has been widely applied in production process, with a considerable number of studies in this field (Dennis, 2008). However, there have been difficulties in adapting Lean concepts and assumptions to Logistics, although lean philosophy can potentially provide benefits for this field (Zylstra, 2008). Therefore, there are opportunities for the development of studies that map and generate information on the current literature state in the Lean and Six Sigma Logistics area, such as systematic reviews.

In this sense, the review in Gonçales Filho et al. (2014) comprehended the strategy in Lean manufacturing in different industry segments. As a result, it was observed the Processing Industry was the most representative, followed by the Automobile and Service Industries. Furthermore, the authors identified opportunities for studies on specific Industries such as Sugarcane-based Energy, which represented a high potential of application.

Similarly, Khorasani et al. (2015) performed a systematic review on Lean Supply Chain Management applied to the Healthcare context. The papers were categorized according to their relevance, scope, methodology, type of industry and year of publication, and results demonstrated that the selected papers focused on the application of Lean methodology to reduce costs, increase time efficiency and quality. In addition, the most studied topics were identified as being technology in the Supply Chain and its implementation factors, and the main methodologies were data mining, surveys, simulation, optimization models and Value Stream Mapping. The authors suggest future studies on practical application of theoretical articles.

In this context, considering the research opportunities for connecting Lean, Six Sigma and Logistic concepts in the literature, this study aimed to characterize the current state of the literature on Lean Logistics (LL) and Six Sigma Logistics (SSL), using a systematic review approach for analyzing pa- pers published from 2012 to 2016 . For this purpose, along with the review protocol, research questions were provided to guide data collection from the selected papers in terms of theory, application, Lean tools, Six Sigma concepts, methodology and Logistic concepts. Therefore, the contribution of this study comprehends the identification of the main topics covered in literature of LL and SSL as well as new research opportunities for the practices.

This study is organized as follows: Section 1 provides a brief introduction to the study, justifying its contribution and objectives; Section 2 presents a detailed description of the systematic review methodology; Section 3 contains the analysis of data collected from the selected papers and the discussion on the LL and SSL current context. Finally, in Section 4 , conclusions and final thoughts on the results achieved are exposed.

\section{METHODOLOGY}

It is important to follow proper guidelines to conduct a systematic review to ensure a valid and unbiased analysis. Therefore, a systematic review protocol was elaborated with guidelines for the entire review process. Afterwards, following the inclusion and exclusion criteria, papers were selected to compose the final analysis. Finally, a complete reading and analysis on those papers was performed to collect information to answer a set of research questions and describe the current panorama of LL e SSL studies. These methodology steps are systematically illustrated in Figure 1.

The research protocol that led this systematic review is summarized in Table 1. In order to clarify the criteria adopted in the protocol, it is important to comment the connection between lean and six sigma considered in the review.

The combination of lean and six sigma concepts results in a powerful combination of tools, techniques and methods for management and control analysis. According to Goldsby et Martichenko (2005), combining lean concepts and techniques with six sigma methods from logistics perspective results in waste reduction caused by regulated efforts to understand and decrease variation, simultaneously increasing velocity and material flow performance in the logistics and supply chain.

The papers resulted from the search using keywords and the Boolean operators were matched with the protocol guidelines, and those aligned with the inclusion criteria were selected for this review. It is worth mentioning the necessity of a subjective analysis in this phase: the sensibility and knowledge of the authors about the subject, since some articles did not directly state the approach of LL or SSL, 


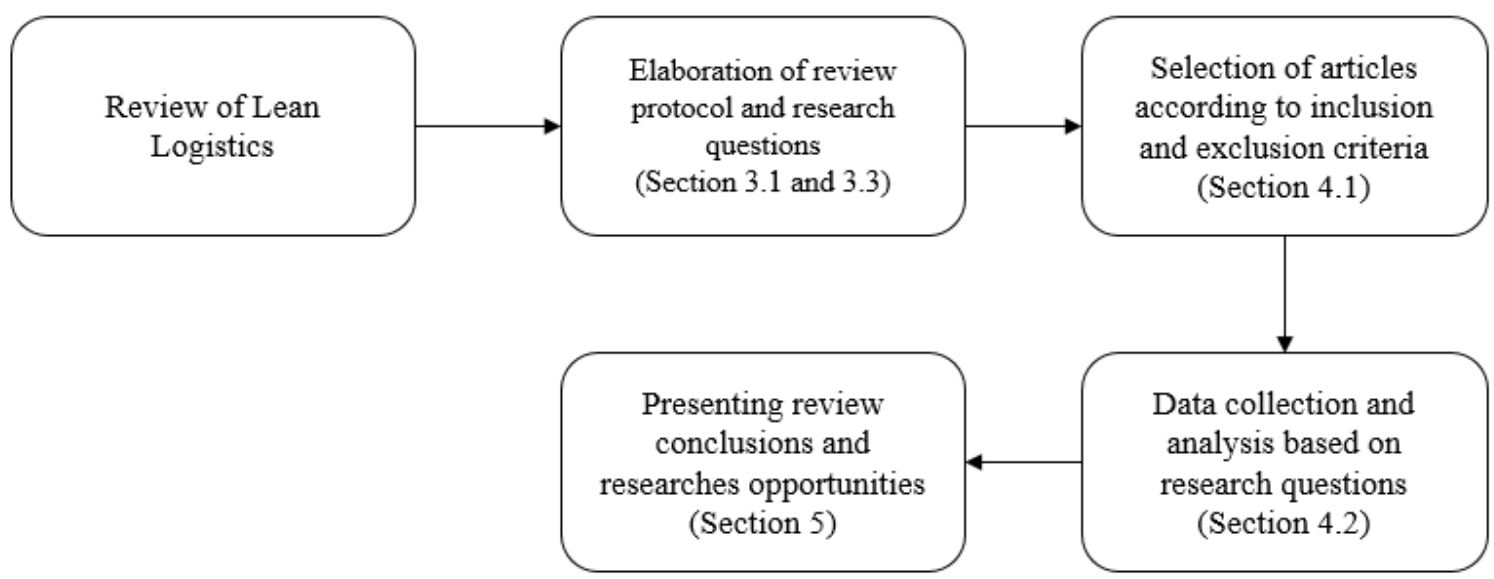

Figure 1. Methodology steps for the proposed systematic review

Source: Adapted from Negrão et al. (2016)

making necessary to analyze carefully the published studies' content. Papers were selected with full accordance between the authors, and duplicates were removed.

Table 1. Review protocol parameters for the systematic review on $\mathrm{LL}$ and SSL

RESEARCH PROTOCOL

Main Research Question: "What is the current literature state of Lean Logistics (LL) and Six Sigma Logistics (SSL)?"

\begin{tabular}{|c|c|c|c|}
\hline Keywords & Period & Inclusion criteria & Databases \\
\hline "Logística & \multirow{9}{*}{$\begin{array}{l}2012- \\
2016\end{array}$} & $\begin{array}{l}\text { Papers in journals } \\
\text { and conferences }\end{array}$ & \multirow{5}{*}{$\begin{array}{l}\text { Science Direct } \\
\text { CAPES Jour- } \\
\text { nals } \\
\text { Web of Sci- } \\
\text { ence } \\
\text { SCOPUS }\end{array}$} \\
\hline “Logística & & $\begin{array}{l}\text { Papers that pre- } \\
\text { cisely state LL and } \\
\text { SSL in its content }\end{array}$ & \\
\hline Lean" & & $\begin{array}{l}\text { or that relate lean } \\
\text { thinking or six } \\
\text { sigma with at least }\end{array}$ & \\
\hline tics" & & $\begin{array}{l}\text { one logistics driver, } \\
\text { being able to iden- } \\
\text { tify this information }\end{array}$ & \\
\hline Seis Sigma" & & $\begin{array}{c}\text { in the title, abstract } \\
\text { or keywords }\end{array}$ & \\
\hline “Logística & & Papers in Portu- & \multirow{4}{*}{$\begin{array}{l}\text { Google } \\
\text { Scholar }\end{array}$} \\
\hline Six Sigma" & & $\begin{array}{l}\text { guese, tnglish or } \\
\text { Spanish }\end{array}$ & \\
\hline \multirow{2}{*}{$\begin{array}{l}\text { "Six Sigma } \\
\text { Logistics" }\end{array}$} & & Exclusion criteria & \\
\hline & & $\begin{array}{l}\text { Articles on Lean } \\
\text { only }\end{array}$ & \\
\hline
\end{tabular}

Source: The author(s)' own

The next step was to perform a detailed reading on the selected papers to extract their respective information based on a set of research questions (RQ), as shown in Table 2 , along with their respective objectives. These $R Q$ aimed to identify trends and gaps in the current literature.
For RQ-1, it was proposed a set of multiple-choice alternatives: a) Logistics and Lean or six sigma concepts are linked (when both concepts are connected, presenting lean or six sigma logistics integrated theories). b) The concepts are not linked (when it presents either only concepts of logistics, or lean thinking, or six sigma or both, but not relating them clearly in the literature review). c) It does not contain specific literature review topics (when none of the concepts is presented in a specific theoretical topic or the literature review section could not be identified in the paper).

In RQ-2, the answer could be one or more logistics operational drivers, since it is possible to approach more than one simultaneously. Therefore, the answer options were: a) Transportation; b) Inventory; c) Facility; d) Information; and e) Not defined, in cases where there was not a clear definition or the study was not restricted to these drivers.

RQ-3 allowed the classification of the selected papers according its applicability. The answer was "applied" when the paper's results were composed of purely practical content application in some sector or organization - although the sector was not clearly defined in some cases. On the other hand, when results were composed of only theoretical content, without practical application, the paper was considered theoretical.

For RQ-4, it could be identified more than one tool/principle in each paper. For the cases when there was no application of a certain tool or it was not explicitly specified, the question was not applicable. The range of tools was adapted from Negrão et al. (2016).

RQ-5 intended to gather the paper's application sectors within the articles. The range of economic and industrial activity sector was defined according to the National Economic Activity Code (CNAE 2.0) of the Brazilian Institute of Geography and Statistics (IBGE, 2017). If a sector was not clearly 
specified, then the answer for this was "not defined". If the paper was theoretical and not applied in any sector, the answer was "not applicable".

Table 2. Research questions and their objectives

\begin{tabular}{|c|c|c|}
\hline ID & Research Question & Objective \\
\hline RQ-1 & $\begin{array}{c}\text { In the paper's litera- } \\
\text { ture review, was there } \\
\text { connection between } \\
\text { logistics and lean thinking } \\
\text { concepts? }\end{array}$ & $\begin{array}{l}\text { Verify the level of integra- } \\
\text { tion between the logistics } \\
\text { and lean thinking concepts }\end{array}$ \\
\hline$R Q-2$ & $\begin{array}{c}\text { Which logistics opera- } \\
\text { tional driver is the lean } \\
\text { logistics principle applied } \\
\text { in? }\end{array}$ & $\begin{array}{c}\text { Identify which logistics } \\
\text { operational drivers (facility, } \\
\text { inventory, transportation } \\
\text { and information) the lean } \\
\text { philosophy has been applied } \\
\text { more frequently. }\end{array}$ \\
\hline$R Q-3$ & $\begin{array}{l}\text { Is the paper a theoretical } \\
\text { research or an applica- } \\
\text { tion in some productive/ } \\
\text { industrial sector? }\end{array}$ & $\begin{array}{l}\text { Define what is more com- } \\
\text { mon: theoretical studies on } \\
\text { lean logistics application } \\
\text { and impacts, or effective } \\
\text { establishment of lean phi- } \\
\text { losophy in the proposition } \\
\text { of specific logistics results }\end{array}$ \\
\hline RQ-4 & $\begin{array}{l}\text { What lean logistics tools } \\
\text { and/or principles does } \\
\text { the article addresses? }\end{array}$ & $\begin{array}{l}\text { Identify how logistics has } \\
\text { been applied in organiza- } \\
\text { tions based on the lean } \\
\text { tools utilized and if there is } \\
\text { a trend on its utilization }\end{array}$ \\
\hline$R Q-5$ & $\begin{array}{l}\text { What productive/indus- } \\
\text { trial/economic sector the } \\
\text { article focuses on? }\end{array}$ & $\begin{array}{l}\text { Identify in which produc- } \\
\text { tive, industrial or economy } \\
\text { sectors the lean logistics } \\
\text { approach has been more } \\
\text { commonly applied. }\end{array}$ \\
\hline RQ-6 & $\begin{array}{l}\text { What wastes tackled by } \\
\text { lean logistics does the } \\
\text { article address? }\end{array}$ & $\begin{array}{l}\text { Define the main problems } \\
\text { and wastes that motivate } \\
\text { proposal of studies and ap- } \\
\text { plication of lean logistics }\end{array}$ \\
\hline
\end{tabular}

Source: The author(s)' own
Finally, in RQ-6, the alternatives for answer were based on the seven wastes defined by Goldsby et Martichenko (2005), which are: Inventory; Transportation; Space and Facilities; Time; Packaging; Administration; and Knowledge. When it was not clear what waste was being tackled, the answer would be "not defined". It was possible to select more than one alternative, since it is common to tackle more than one type of waste simultaneously in lean systems.

\section{RESULTS AND ANALYSIS}

The results of the systematic review were presented in this section, which comprises the information obtained from collection and analysis of the selected papers based on the proposed protocol and research questions, aiming to verify the current scenario of the LL and SSL literature. A set of parameters was created for analysis (research question's answers) for each research question (RQ), thus, for the systematic review. In Figure 2 all sets of criteria and their respective code are described.

Based on the review protocol, it was obtained a sample of 67 papers, varying in terms of language, country of publication and lean or six sigma logistics approach. In Table 3, a summary about those papers is presented, along with each $\mathrm{RQ}$ analysis.

In terms of language, one can verify the majority of papers were written in English, representing 64\%, followed by $28 \%$ in Portuguese, and $8 \%$ in Spanish, as illustrated in Figure 3 .

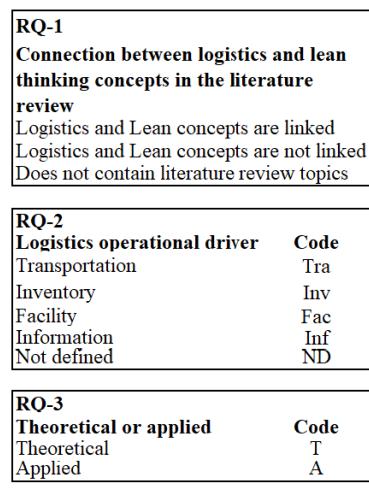

*National Economic Activity Code (CNAE 2.0) of the Brazilian Institute of Geography and Statistics (IBGE)

\begin{tabular}{|c|c|c|c|}
\hline \\
\hline $\begin{array}{l}\text { Lean logistics tools and } \\
\text { principles }\end{array}$ & Code & $\begin{array}{l}\text { Lean logistics tools and } \\
\text { principles }\end{array}$ & Code \\
\hline Kanban & Kan & Radio Frequency Identification & RFID \\
\hline $5 \mathrm{~S}$ & $5 \mathrm{~S}$ & Single Minute Exchange of Die & SMED \\
\hline $5 \mathrm{~W} 2 \mathrm{H}$ & $5 \mathrm{~W} 2 \mathrm{H}$ & SIPOC & SIPOC \\
\hline A3 Problem Solving & A3 & Six Sigma & SS \\
\hline Batch size reduction & Batch & Spaghetti Diagram & Spagh \\
\hline Constant Work in Progress & Cwip & Standardizati & Standz \\
\hline Continuous flow & ContFlw & Takt Time & Tkt \\
\hline Eletronic Data Interchange & EDI & Teamwork & Team \\
\hline ise Resource Planning & ERP & Total Productive Maintenance & TPM \\
\hline Global Operating Income Index & IROG & Total Quality Management & $\mathrm{TQM}$ \\
\hline Kaizen & Kai & Value Stream Mapping & VSM \\
\hline Layout & Lyt & Variation Control & Vari \\
\hline Logistics Personal Excellence & Lopec & Vendor Managed Inventory & VMI \\
\hline Milk-Run & Mlk & Visual Management System & Visu \\
\hline Overall Equipment Effectiveness & OEE & Wate & WS \\
\hline Performance Measure System & PMS & Workplace Management & WorkM \\
\hline $\mathrm{Pla}$ & PFEP & None/not defined & $\mathrm{n} / \mathrm{a}$ \\
\hline ust in Time & JIT & & \\
\hline
\end{tabular}

Figure 2. Criteria and coding for each research question

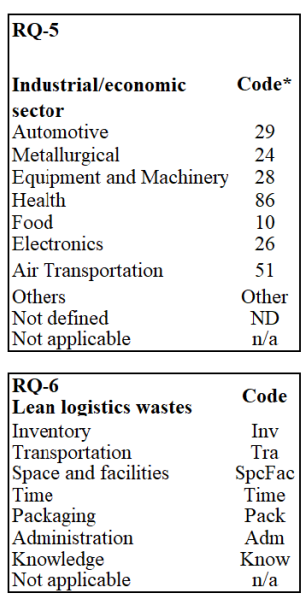


Table 3. Classification and summary of the lean logistics papers

\begin{tabular}{|c|c|c|c|c|c|c|c|c|}
\hline Main results & RQ-6 & RQ-5 & RQ-4 & RQ-3 & RQ-2 & RQ-1 & Country & Authors \\
\hline $\begin{array}{c}\text { Development of a tool for quantifying val- } \\
\text { ue-added shares in material supply as a main } \\
\text { task of logistics. The value-added shares of } \\
\text { commissioning are identified and reasons for } \\
\text { losses are discussed }\end{array}$ & Time & ND & OEE & A & ND & Nolink & Germany & $\begin{array}{l}\text { Adolph et. } \\
\text { al, } 2016\end{array}$ \\
\hline $\begin{array}{l}\text { The implementation of the comprehensive } \\
\text { plan has reduced inventory, decreased lead } \\
\text { time and improved service quality, enhanced } \\
\text { employee satisfaction and increased staff } \\
\text { productivity, both dedicated to health and } \\
\text { logistics }\end{array}$ & $\begin{array}{c}\text { Time, } \\
\text { Inv, Adm }\end{array}$ & 86 & Kan & A & $\begin{array}{c}\text { Inv, } \\
\text { Fac, Inf }\end{array}$ & Noliterat & Spain & $\begin{array}{l}\text { Aguilar-Es- } \\
\text { cobar et } \\
\text { Garrido-Ve- } \\
\text { ga, } 2013\end{array}$ \\
\hline $\begin{array}{l}\text { Reduction in logistics costs and increase in } \\
\text { the satisfaction level of the internal hospital } \\
\text { users with the new logistics system. Some } \\
\text { differences in the degree of satisfaction by } \\
\text { different groups of users were detected }\end{array}$ & $\begin{array}{l}\text { Inv, } \\
\text { Time, } \\
\text { Adm }\end{array}$ & 86 & $n / a$ & A & $\mathrm{Fac}$ & Noliterat & Spain & $\begin{array}{l}\text { Aguilar-Es- } \\
\text { cobar et al., } \\
\quad 2013\end{array}$ \\
\hline $\begin{array}{c}\text { Through improving service time, lean caused } \\
\text { positive impact towards Tam Cargo clients. A } \\
\text { layout change allowed better cargo organiza- } \\
\text { tion in operational processes. The company } \\
\text { has been adjusting its costs according to } \\
\text { demand, practice that is aligned with lean } \\
\text { philosophy }\end{array}$ & SpcFac & 51 & $\begin{array}{c}\text { 5S, Kan, } \\
\text { SS, Lyt }\end{array}$ & A & $\mathrm{Fac}$ & Link & Brazil & $\begin{array}{l}\text { Almeida } \\
\text { Filho et } \\
\text { Lobosco, } \\
2015\end{array}$ \\
\hline $\begin{array}{c}\text { There is a lack of studies regarding in-plant } \\
\text { milk run system as a whole, and in certain } \\
\text { areas of the system, such as manual feeding. } \\
\text { There is also a tendency to deviate from lean } \\
\text { manufacturing philosophy, looking for opti- } \\
\text { mality based on restrictive objectives }\end{array}$ & Tra & ND & Mlk, JIT & T & Tra & Link & Germany & $\begin{array}{c}\text { Alnahhal et } \\
\text { al., } 2014\end{array}$ \\
\hline $\begin{array}{l}\text { Reduced number of stock out incidents by } \\
\text { applying the DMAIC methodology in the } \\
\text { healthcare logistics management }\end{array}$ & $n / a$ & 86 & SS & A & $\operatorname{lnv}$ & Link & Jordan & $\begin{array}{l}\text { Al-Qataw- } \\
\text { neh et al., } \\
2013\end{array}$ \\
\hline $\begin{array}{l}\text { Proposed ideas for a lean logistics system to } \\
\text { prevent problems caused by failure on de- } \\
\text { mand, sales and production forecast, which } \\
\text { were proven unstable and inaccurate }\end{array}$ & Inv, Time & 10 & Kan & A & Inv, Fac & Link & Brazil & $\begin{array}{l}\text { Alves et } \\
\text { Santos, } \\
2013\end{array}$ \\
\hline $\begin{array}{l}\text { Applied the four phases of the DMAIC meth- } \\
\text { odology, which showed the necessity to pay } \\
\text { attention and focus on personal capacity, job } \\
\text { rotation, usage of trucks with an hydraulic } \\
\text { system and sample size }\end{array}$ & SpcFac & 28 & SS & A & $\ln v$ & Noliterat & Peru & $\begin{array}{l}\text { Ángeles, } \\
2013\end{array}$ \\
\hline $\begin{array}{l}\text { Reduction of defects in } 80 \% \text {, improvements } \\
\text { in the customer service and increase in pro- } \\
\text { ductivity in supermarket and repacking areas }\end{array}$ & Tra & 29 & \begin{tabular}{|c|}
$\begin{array}{c}\text { Kan, MIk, } \\
\text { TQM, SS, } \\
\text { JIT }\end{array}$ \\
\end{tabular} & A & Tra & Nolink & England & $\begin{array}{c}\text { Antunes et } \\
\text { al., } 2013\end{array}$ \\
\hline $\begin{array}{c}\text { Discusses milk run logistics in the line feeding } \\
\text { system with a special emphasis on the auto- } \\
\text { mobile industry, which leads to the enhance- } \\
\text { ment of logistics indices }\end{array}$ & \begin{tabular}{|} 
SpcFac, \\
Inv, Tra, \\
Adm, \\
Time \\
\end{tabular} & 29 & $\begin{array}{l}\text { 5S, Mlk, } \\
\text { Standz }\end{array}$ & A & $\begin{array}{c}\text { Tra, } \\
\text { Fac, Inf }\end{array}$ & Nolink & - & $\begin{array}{l}\text { Bagheri et } \\
\text { al., } 2016\end{array}$ \\
\hline $\begin{array}{l}\text { A survey conducted in the } 126 \text { organizations } \\
\text { showed the use the lean in logistics process } \\
\text { regardless of the type of production, which } \\
\text { is related to the complexity of the logistics } \\
\text { system. The order of methods frequently } \\
\text { used is Teamwork, 5S, KAIZEN, TPM, KANBAN } \\
\text { and VSM. }\end{array}$ & $n / a$ & ND & $\begin{array}{l}\text { 5S, Kai, } \\
\text { Kan, } \\
\text { VSM, } \\
\text { TPM, } \\
\text { Team }\end{array}$ & A & ND & Noliterat & Slovakia & $\begin{array}{l}\text { Bednár et } \\
\text { al., 2013b }\end{array}$ \\
\hline
\end{tabular}




\begin{tabular}{|c|c|c|c|c|c|c|c|c|}
\hline $\begin{array}{c}\text { The article showed how logistics is responsi- } \\
\text { ble for how fast and efficiently the customer } \\
\text { will receive their product and the benefits of } \\
\text { lean techniques applied directly and indirect- } \\
\text { ly in logistics processes }\end{array}$ & $\begin{array}{l}\text { Inv, Adm, } \\
\text { Time }\end{array}$ & 29 & $\begin{array}{l}\text { 5S, Visu, } \\
\text { Kai, Kan, } \\
\text { VSM, } \\
\text { Tkt, } \\
\text { TPM, } \\
\text { Team } \\
\end{array}$ & $A$ & Tra, Fac & Nolink & Slovakia & $\begin{array}{l}\text { Bednár et } \\
\text { al., 2012a }\end{array}$ \\
\hline $\begin{array}{l}\text { Proposed lean logistics concepts focusing on } \\
\text { customer services and visibility of wastes in } \\
\text { the metallurgical sector in order to achieve } \\
\text { global efficiency }\end{array}$ & $\begin{array}{l}\text { Tra, Inv, } \\
\text { Time }\end{array}$ & 24 & $\begin{array}{l}\text { VSM, } \\
\text { Kan, JIT, } \\
\text { Standz, } \\
\text { Lyt }\end{array}$ & $\mathrm{T}$ & $\begin{array}{c}\text { Tra, Inv, } \\
\text { Inf }\end{array}$ & Link & Brazil & Belli, 2012 \\
\hline $\begin{array}{l}\text { Implemented Kaizen and a RFID system to } \\
\text { control } 100 \% \text { of product movement. Resulted } \\
\text { in the reduction of human error, increasing in } \\
\text { logistics processes' informatization and auto- } \\
\text { mation, and reduction of time in expedition } \\
\text { processes and inventory }\end{array}$ & $\begin{array}{l}\text { Inv, Adm, } \\
\text { Time }\end{array}$ & 29 & $\begin{array}{l}\text { 5S, Kai, } \\
\text { SS, RFID }\end{array}$ & $A$ & Inv & Nolink & Brazil & $\begin{array}{l}\text { Benevides } \\
\text { et al., } 2013\end{array}$ \\
\hline $\begin{array}{l}\text { Taught the adequate application of Industry } \\
4.0 \text { technology in production logistics and } \\
\text { evaluated the specific problems of logistics } \\
\text { planning in the field of "intelligent production } \\
\text { logistics" with a survey }\end{array}$ & $\mathrm{n} / \mathrm{a}$ & Other & JIT & $A$ & Inf & Noliterat & Germany & $\begin{array}{l}\text { Blöchl et } \\
\text { Schneider, } \\
2016\end{array}$ \\
\hline $\begin{array}{l}\text { Applied lean techniques towards improve- } \\
\text { ments in a company's internal logistics. a } \\
\text { shipping and receiving window, internal } \\
\text { supply routes, flexible storage and a milk-run } \\
\text { system were planned. The projected annual } \\
\text { earnings in labor and equipment are } \mathrm{R} \$ \\
316.718 \text { and } \mathrm{R} \$ 27.886 \text {, respectively. }\end{array}$ & $\begin{array}{l}\text { Inv, Tra, } \\
\text { Pack, } \\
\text { Time }\end{array}$ & 24 & $\begin{array}{l}\text { 5S, A3, } \\
\text { Mlk, JIT, } \\
\text { SMED, } \\
\text { ContFIw }\end{array}$ & $A$ & Tra, Inv & Nolink & Brazil & $\begin{array}{l}\text { Carreira et } \\
\text { Sobrinho, } \\
2012\end{array}$ \\
\hline $\begin{array}{l}\text { The use of DMADV methodology allows to } \\
\text { systematically stablish a model. Created an } \\
\text { online community (Be One Logistics) whose } \\
\text { membership fee increased to } 71 \% \text { of the } \\
\text { target population }\end{array}$ & $\mathrm{n} / \mathrm{a}$ & 29 & SS & $A$ & Inf & Nolink & Portugal & $\begin{array}{c}\text { Carvalho et } \\
\text { al., } 2016\end{array}$ \\
\hline $\begin{array}{l}\text { Reduction in production costs and im- } \\
\text { provements in the quality of products were } \\
\text { consequences of the lean implementation. } \\
\text { It was observed that lean inventory depends } \\
\text { on a series of activities, whether related with } \\
\text { inventory management or not. }\end{array}$ & $\begin{array}{l}\text { Inv, } \\
\text { Time, } \\
\text { Tra }\end{array}$ & 24 & $\begin{array}{c}\text { Visu, Kai, } \\
\text { Kan, Mlk, } \\
\text { TQM, } \\
\text { Batch, } \\
\text { Tkt, } \\
\text { Standz, } \\
\text { PFEP, } \\
\text { EDI }\end{array}$ & $A$ & $\begin{array}{l}\text { Tra, Inv, } \\
\text { Inf, Fac }\end{array}$ & Nolink & Brazil & $\begin{array}{c}\text { Catapan et } \\
\text { al., } 2013\end{array}$ \\
\hline $\begin{array}{c}\text { Proposed a logistics project approach using } \\
\text { the DMAIC methodology to eliminate waste } \\
\text { from flows and operations, lower delivery } \\
\text { times, reduce process variance, and increase } \\
\text { value in companies }\end{array}$ & $\begin{array}{l}\text { Time, } \\
\text { Tra, } \\
\text { SpcFac }\end{array}$ & $\mathrm{n} / \mathrm{a}$ & $\begin{array}{l}\text { VSM, } \\
\text { TQM, SS, } \\
\text { Standz } \\
\text { TPM, } \\
\text { Visu, } \\
\text { 5S, Vari, } \\
\text { Batch }\end{array}$ & $\mathrm{T}$ & Inf & Link & $\begin{array}{l}\text { Colom- } \\
\text { bia and } \\
\text { Mexico }\end{array}$ & $\begin{array}{l}\text { Celis et } \\
\text { García, } \\
2012\end{array}$ \\
\hline $\begin{array}{l}\text { Reduction of } 61 \% \text { in the logistics operator's } \\
\text { idle waiting time and of } 26 \% \text { in the total } \\
\text { duration of a material supply route. Improved } \\
\text { the system efficiency and material handling. }\end{array}$ & $\begin{array}{l}\text { Time, } \\
\text { Pack }\end{array}$ & 29 & $\begin{array}{c}\text { A3, Visu, } \\
\text { Tkt, Lyt }\end{array}$ & $A$ & Tra, Fac & Noliterat & Brazil & $\begin{array}{c}\text { Costa and } \\
\text { Costa, } 2016\end{array}$ \\
\hline $\begin{array}{c}\text { Applied a kanban system in equipment and } \\
\text { machinery industry, reducing extra storage } \\
\text { space on the shelves, leaning in the entire } \\
\text { process and facilitating the stock replenish- } \\
\text { ment }\end{array}$ & Inv & 28 & $\begin{array}{c}\text { Visu, } \\
\text { Kan, Lyt }\end{array}$ & $A$ & Inv & Nolink & Brazil & $\begin{array}{l}\text { Domingos } \\
\text { et al., } 2013\end{array}$ \\
\hline
\end{tabular}




\begin{tabular}{|c|c|c|c|c|c|c|c|c|}
\hline $\begin{array}{l}\text { Provides practitioners with answers to the } \\
\text { question about which performance indicators } \\
\text { to use in today's automotive logistics chain } \\
\text { and which indicators serve as a base for con- } \\
\text { tinuous improvement }\end{array}$ & $\begin{array}{l}\text { Inv, } \\
\text { Time, } \\
\text { Tra }\end{array}$ & 29 & PMS & $A$ & Tra & Link & Germany & $\begin{array}{l}\text { Dornhofer } \\
\text { et al., } 2016\end{array}$ \\
\hline $\begin{array}{l}\text { Affirms that lean logistics can be applied in } \\
\text { any distribution company, which will possibly } \\
\text { reduce costs and wasted time, making logis- } \\
\text { tics processes more efficient and effective }\end{array}$ & Time, Tra & Other & $\mathrm{n} / \mathrm{a}$ & A & Tra, Fac & Link & Brazil & $\begin{array}{l}\text { Ferreira } \\
\text { et Magno, } \\
2013\end{array}$ \\
\hline $\begin{array}{l}\text { Introduces a learning methodology through } \\
\text { lean logistics projects, in which the work- } \\
\text { er effectively contributes with theory and } \\
\text { practices }\end{array}$ & Time & Other & $\mathrm{n} / \mathrm{a}$ & A & Tra & Link & Brazil & $\begin{array}{c}\text { Ferreira et } \\
\text { al., } 2014\end{array}$ \\
\hline $\begin{array}{c}\text { The concurrent deployment of the green } \\
\text { and lean paradigms is an effective approach } \\
\text { to improve both operational efficiency and } \\
\text { environmental performance of road transport } \\
\text { operations }\end{array}$ & Tra & ND & VSM & A & Tra & Nolink & $\begin{array}{l}\text { England } \\
\text { and Mex- } \\
\text { ico }\end{array}$ & $\begin{array}{l}\text { Gar- } \\
\text { za-Reyes, et } \\
\text { al.,2016 }\end{array}$ \\
\hline $\begin{array}{c}\text { Identified patterns in publications on lean } \\
\text { logistics and supply from } 2005 \text { to } 2014 \text {, such } \\
\text { as publication platform and business segment } \\
\text { in which the concepts were applied }\end{array}$ & $\mathrm{n} / \mathrm{a}$ & $\mathrm{n} / \mathrm{a}$ & $\mathrm{n} / \mathrm{a}$ & $\mathrm{T}$ & ND & Link & Brazil & $\begin{array}{l}\text { Gonçales } \\
\text { Filho et al., } \\
2014\end{array}$ \\
\hline $\begin{array}{l}\text { Identify important implementation aspects } \\
\text { when applying Lean Six Sigma to logistics } \\
\text { services, such as continuous improvement } \\
\text { structure, strategic analysis and process } \\
\text { management }\end{array}$ & $\mathrm{n} / \mathrm{a}$ & 26 & $\begin{array}{l}\text { Visu, } \\
\text { VSM, SS, } \\
\text { SIPOC }\end{array}$ & A & ND & Nolink & $\begin{array}{l}\text { Nether- } \\
\text { lands }\end{array}$ & $\begin{array}{l}\text { Gutier- } \\
\text { rez-Gutier- } \\
\text { rez et al., } \\
2016\end{array}$ \\
\hline $\begin{array}{l}\text { Results from fit hypothesis tests in two logis- } \\
\text { tics service providers indicated that challeng- } \\
\text { ing and enabling workers to creatively use } \\
\text { their talents and skills in daily work will most } \\
\text { likely lead to positive results }\end{array}$ & Know & ND & $\mathrm{n} / \mathrm{a}$ & $A$ & ND & Nolink & $\begin{array}{l}\text { Nether- } \\
\text { lands }\end{array}$ & $\begin{array}{c}\text { Haan et al., } \\
2012\end{array}$ \\
\hline $\begin{array}{l}\text { Logistics Personal Excellence will provide } \\
\text { training modules for post-secondary edu- } \\
\text { cation in the area of lean logistics, required } \\
\text { basic skills and transparency of personal } \\
\text { excellence with a personal self-assessment } \\
\text { software solution, regarding the personal ma- } \\
\text { turity level of hard and soft skills at any time }\end{array}$ & Know & $\mathrm{n} / \mathrm{a}$ & Lopec & $\mathrm{T}$ & Inf & Noliterat & Austria & $\begin{array}{l}\text { Jäger et al., } \\
2014\end{array}$ \\
\hline $\begin{array}{l}\text { Implemented a kanban system for a produc- } \\
\text { tion line, thus reducing warehouse inventory } \\
\text { and people/material motion. There were } \\
\text { improvements associated with material avail- } \\
\text { ability in the logistic process }\end{array}$ & Adm, Inv & 28 & $\begin{array}{l}\text { 5S, Kan, } \\
\text { VSM }\end{array}$ & $A$ & Inv & Nolink & Brazil & $\begin{array}{c}\text { Kach et al., } \\
2015\end{array}$ \\
\hline $\begin{array}{c}\text { The results of this study revealed that despite } \\
\text { the management style, } 88 \% \text { of managers } \\
\text { believe Six Sigma is compatible with logistics } \\
\text { managers' roles and responsibilities. Further- } \\
\text { more, adaptation of logistics processes to Six } \\
\text { Sigma requirements proved more compatible } \\
\text { than otherwise. }\end{array}$ & $\mathrm{n} / \mathrm{a}$ & ND & $\mathrm{n} / \mathrm{a}$ & $A$ & ND & Link & $\begin{array}{l}\text { US, Cana- } \\
\text { da, Turkey }\end{array}$ & $\begin{array}{l}\text { Khoury et } \\
\text { al., } 2013\end{array}$ \\
\hline $\begin{array}{l}\text { The milk-run distribution problem is Catego- } \\
\text { rized and explained in the plants, based on } \\
\text { observations in real manufacturing environ- } \\
\text { ment. Modeling is performed to minimize the } \\
\text { number of vehicles and the distance traveled }\end{array}$ & $\begin{array}{l}\text { Tra, } \\
\text { SpcFac }\end{array}$ & $\mathrm{n} / \mathrm{a}$ & Mlk & $\mathrm{T}$ & Tra & Nolink & Turkey & $\begin{array}{l}\text { Kilic et al., } \\
2012\end{array}$ \\
\hline
\end{tabular}




\begin{tabular}{|c|c|c|c|c|c|c|c|c|}
\hline $\begin{array}{l}\text { Strategies for handling delivery peaks on } \\
\text { milk-run systems and evaluation regarding } \\
\text { delivery cost, lead time and service level, } \\
\text { using real material consumption data from } \\
\text { two large companies from the automotive } \\
\text { industry } \\
\end{array}$ & Time, Tra & 29 & $\begin{array}{c}\text { Kan, Mlk, } \\
\text { Vari }\end{array}$ & $A$ & Tra & Nolink & Germany & $\begin{array}{c}\text { Klenk et al., } \\
2015\end{array}$ \\
\hline $\begin{array}{l}\text { Analyzed the various kinds of disturbances } \\
\text { occurring in the production and management } \\
\text { decision on the production stability and } \\
\text { performance by developing a discrete-event } \\
\text { simulation model }\end{array}$ & $n / a$ & ND & Mlk, Tkt & A & Tra & Nolink & Poland & $\begin{array}{l}\text { Korytkowski } \\
\text { et Karkosz- } \\
\text { ka, } 2016\end{array}$ \\
\hline $\begin{array}{c}\text { The results of design using Lean and RFID } \\
\text { showed that the Germinated Brow Rice (GBR) } \\
\text { logistics operations significantly reduced time } \\
\text { from } 3,731.5 \text { to } 617 \text { minutes, accounting for } \\
16.53 \%\end{array}$ & $\begin{array}{c}\text { Tra, } \\
\text { SpcFac }\end{array}$ & Other & VSM & $A$ & Inf & Nolink & Thailand & $\begin{array}{c}\text { Kravenkit } \\
\text { et Arch-int, } \\
2013\end{array}$ \\
\hline $\begin{array}{l}\text { Presented the benefits of lean production } \\
\text { and distribution, together with statistics in } \\
\text { percentage of road, rail, air, and water trans- } \\
\text { port, used today in the world }\end{array}$ & Tra & $n / a$ & $\begin{array}{l}\text { Batch, } \\
\text { Vari }\end{array}$ & $\mathrm{T}$ & Tra & Link & Slovakia & $\begin{array}{l}\text { Kubasáková } \\
\text { et Polia- } \\
\text { ková, } 2014\end{array}$ \\
\hline $\begin{array}{c}\text { Increased customer satisfaction in a logistics } \\
\text { center by reducing the credit voucher waiting } \\
\text { time from } 14 \text { days to } 14 \text { min and the error } \\
\text { rate in the refund process is down to almost } \\
\text { zero }\end{array}$ & Time & ND & SS & $A$ & ND & Noliterat & China & $\begin{array}{l}\text { Lee et al., } \\
2013\end{array}$ \\
\hline $\begin{array}{l}\text { Care pathways were the preferred approach } \\
\text { by } 43 \% \text { of the hospitals in the sample, } \\
\text { followed by business process re-engineering } \\
\text { and lean six sigma, with } 13 \% \text {. Flowcharts } \\
\text { were the most common tool, in } 94 \% \text { of the } \\
\text { hospitals }\end{array}$ & $n / a$ & 86 & TQM, SS & A & ND & Nolink & $\begin{array}{l}\text { Nether- } \\
\text { lands }\end{array}$ & $\begin{array}{l}\text { Lent et al., } \\
2012\end{array}$ \\
\hline $\begin{array}{l}\text { A lean logistics workflow was created for a } \\
\text { pull system, describing about packing, supply } \\
\text { logistics, receiving methods, warehouse logis- } \\
\text { tics, production logistics and IT systems. }\end{array}$ & $\begin{array}{l}\text { Inv, } \\
\text { SpcFac, } \\
\text { Pack }\end{array}$ & 29 & $\begin{array}{l}\text { Visu, Lyt, } \\
\text { Mlk }\end{array}$ & A & $\begin{array}{l}\text { Tra, Inv, } \\
\text { Inf, Fac }\end{array}$ & Link & China & $\begin{array}{l}\text { Li et al., } \\
2014\end{array}$ \\
\hline $\begin{array}{l}\text { Built an evaluation index system covering } \\
\text { general logistics business content. Based } \\
\text { on rough set theory and grey theory, a lean } \\
\text { logistics performance evaluation method is } \\
\text { proposed }\end{array}$ & $n / a$ & ND & $\mathrm{n} / \mathrm{a}$ & A & ND & Nolink & China & $\begin{array}{l}\text { Li et al., } \\
2015\end{array}$ \\
\hline $\begin{array}{c}\text { Countermeasures to implement lean supply } \\
\text { logistics, lean production logistics, lean dis- } \\
\text { tribution logistics, and lean returned logistics } \\
\text { based on the green supply chain }\end{array}$ & $\begin{array}{l}\text { Inv, } \\
\text { Time, } \\
\text { Tra, } \\
\text { SpcFac }\end{array}$ & 29 & $n / a$ & $\mathrm{~T}$ & Tra, Inv & Link & China & $\begin{array}{c}\text { Liang et } \\
\text { Wang, } 2013\end{array}$ \\
\hline $\begin{array}{l}\text { Creation of a map of publications regarding } \\
\text { Lean Logistic Performance Measurement and } \\
\text { a bibliographic portfolio composed of the } \\
\text { most relevant and applicable works in the } \\
\text { field }\end{array}$ & $n / a$ & $n / a$ & $n / a$ & $\mathrm{~T}$ & ND & Noliterat & Brazil & $\begin{array}{c}\text { Loos et } \\
\text { Rodriguez, } \\
2015\end{array}$ \\
\hline $\begin{array}{l}\text { Establishing lean principles in internal lo- } \\
\text { gistics caused processes improvement, cost } \\
\text { reduction of supply logistics and workload } \\
\text { balancing throughout routes }\end{array}$ & Tra, Time & 29 & Kan & A & Tra, Inf & Link & Brazil & $\begin{array}{l}\text { Marodin et } \\
\text { al., } 2012\end{array}$ \\
\hline
\end{tabular}




\begin{tabular}{|c|c|c|c|c|c|c|c|c|}
\hline $\begin{array}{c}\text { Applied lean in the redesign of a machinery } \\
\text { manufacturing industrial company produc- } \\
\text { tion system. Results show that it effectively } \\
\text { led to a new flexible production system and } \\
\text { a new industrial layout capable of respond- } \\
\text { ing to diverse future scenarios of products } \\
\text { demand }\end{array}$ & $\begin{array}{l}\text { SpcFac, } \\
\text { Time, } \\
\text { Adm }\end{array}$ & 28 & $\begin{array}{l}\text { Kan, Lyt, } \\
\text { VSM, } \\
\text { Tkt, OEE, } \\
\text { Spagh }\end{array}$ & $A$ & $\begin{array}{l}\text { Tra, Inv, } \\
\text { Inf, Fac }\end{array}$ & Noliterat & Portugal & $\begin{array}{c}\text { Marques et } \\
\text { al., } 2013\end{array}$ \\
\hline $\begin{array}{l}\text { Concludes that using QLE (Queue Length Es- } \\
\text { timator) is better than conventional program- } \\
\text { ming flow systems, because it improves logis- } \\
\text { tics performance in lean and agile systems. }\end{array}$ & Inv & $\mathrm{n} / \mathrm{a}$ & Cwip & $\mathrm{T}$ & Tra, Inv & Link & Germany & $\begin{array}{c}\text { Mehrsai et } \\
\text { al., } 2014\end{array}$ \\
\hline $\begin{array}{l}\text { States that a tightened management-labor } \\
\text { regime in the form of lean logistic manage- } \\
\text { ment can cause reduced earnings, minimal } \\
\text { workplace autonomy and an unprecedented } \\
\text { increase in the pace of work. It is vital to con- } \\
\text { sider the impact of globalization on workers }\end{array}$ & Know & 10 & $\mathrm{n} / \mathrm{a}$ & $\mathrm{T}$ & ND & Link & Scotland & $\begin{array}{l}\text { Mulholland } \\
\text { et Stewart, } \\
2014\end{array}$ \\
\hline $\begin{array}{l}\text { Proposes the Energy Value Stream Mapping } \\
\text { (EVSM), an adaptation of the current VSM. It } \\
\text { includes transportation processes and input } \\
\text { of time and energy, which exist in production } \\
\text { and logistics processes }\end{array}$ & Time, Tra & ND & VSM & $A$ & Tra & Nolink & Germany & $\begin{array}{l}\text { Muller et } \\
\text { al., } 2014\end{array}$ \\
\hline $\begin{array}{l}\text { A comparison of the processes was execut- } \\
\text { ed before and after the Kaizen. Productivity } \\
\text { increased by } 30 \% \text { and the extra hours for } \\
\text { receiving, checking, planning and dispatch- } \\
\text { ing processes decreased by } 80 \% \text {. Gains of } 1 \\
\text { million reais were estimated per year }\end{array}$ & $\begin{array}{l}\text { Inv, Tra, } \\
\text { time, } \\
\text { SpcFac }\end{array}$ & 86 & $\begin{array}{l}\text { Visu, Kai, } \\
\text { VSM, } \\
\text { Tkt, WS, } \\
\text { Standz, } \\
\text { Lyt }\end{array}$ & $A$ & Tra, Inv & Nolink & Brazil & $\begin{array}{l}\text { Nogueira } \\
\text { Neto et al., } \\
2016\end{array}$ \\
\hline $\begin{array}{l}\text { Suggests solutions for handling port city } \\
\text { congestion problems: formation of a rail } \\
\text { linked logistics village positioned outside the } \\
\text { city peripheries; formation of a waterfront } \\
\text { port system logistics center linked by feeder } \\
\text { vessels and hinterland rail connectivity }\end{array}$ & $\mathrm{n} / \mathrm{a}$ & Other & $\mathrm{n} / \mathrm{a}$ & $\mathrm{T}$ & Tra, Fac & Nolink & Nigeria & $\begin{array}{c}\text { Onyemechi, } \\
2013\end{array}$ \\
\hline $\begin{array}{l}\text { Designed a mathematical model and a heu- } \\
\text { ristic approach to construct the routes of a } \\
\text { milk-run supply system based on JIT, aiming } \\
\text { reduction of product and inventory cost, and } \\
\text { material handling }\end{array}$ & $\begin{array}{l}\text { SpcFac, } \\
\text { Tra, Inv, } \\
\text { Time }\end{array}$ & 29 & Mlk, JIT & $\mathrm{T}$ & Tra & Nolink & India & $\begin{array}{c}\text { Patel et } \\
\text { Patel, } 2013\end{array}$ \\
\hline $\begin{array}{l}\text { The implementation of lean in a metallurgical } \\
\text { company's inventory management lead to } \\
\text { reduction of production costs, improvements } \\
\text { in products' quality, reduction on large safety } \\
\text { stocks with no harm in the service level } \\
\text { offered to the client }\end{array}$ & Inv & 24 & Kan, Mlk & A & Inv, Inf & Nolink & Brazil & $\begin{array}{c}\text { Pinto et al., } \\
2013\end{array}$ \\
\hline $\begin{array}{l}\text { Through the developed RFID-enabled oper- } \\
\text { ation facilities, the materials' collection and } \\
\text { distribution around a Supply Hub in Indus- } \\
\text { trial Park are collaboratively and accurately } \\
\text { executed in a small-lot and high frequency } \\
\text { milk-run mode logistics }\end{array}$ & $\mathrm{n} / \mathrm{a}$ & ND & $\begin{array}{c}\text { Mlk, } \\
\text { RFID, JIT }\end{array}$ & $\mathrm{T}$ & Tra, Inf & Nolink & China & $\begin{array}{c}\text { Qu, et al., } \\
2012\end{array}$ \\
\hline $\begin{array}{c}\text { The use of JIT systems in supply activities } \\
\text { between supplier and client is still narrow. } \\
\text { Noted as well a lack of cooperation between } \\
\text { them, where supplier has little involvement } \\
\text { on process and production design and de- } \\
\text { mand forecast }\end{array}$ & Inv & 24 & JIT & $A$ & Inv & Link & Brazil & $\begin{array}{c}\text { Rocha et al., } \\
2013\end{array}$ \\
\hline
\end{tabular}




\begin{tabular}{|c|c|c|c|c|c|c|c|c|}
\hline $\begin{array}{l}\text { Identified the main supportive and not sup- } \\
\text { portive factors related to the nationalization } \\
\text { of suppliers for and automotive assembler }\end{array}$ & $\mathrm{n} / \mathrm{a}$ & 29 & $n / a$ & A & ND & Link & Brazil & $\begin{array}{l}\text { Sá et al., } \\
2014\end{array}$ \\
\hline $\begin{array}{l}\text { Provides an implementation example of Lean } \\
\text { Six Sigma to improve a logistics supply chain. } \\
\text { It validated the implementation and provided } \\
\text { a description of all phases of DMAIC. An } \\
\text { economy of } 0.8 \text { million dollars was estimated. }\end{array}$ & Inv, Time & 10 & SS & $A$ & Fac & Nolink & Tunisia & $\begin{array}{c}\text { Sadraoui et } \\
\text { Fayza, }\end{array}$ \\
\hline $\begin{array}{l}\text { Proposed a mathematical model and a } \\
\text { heuristic approach to construct an internal } \\
\text { milk-run material supply system, and applied } \\
\text { it in a TV assembly industry }\end{array}$ & $\begin{array}{l}\text { Tra, } \\
\text { Time, } \\
\text { Adm }\end{array}$ & 26 & Mlk, JIT & A & Tra & Link & Turkey & $\begin{array}{c}\text { Satogu et } \\
\text { Sahin, } 2013\end{array}$ \\
\hline $\begin{array}{l}\text { Six Sigma is applicable and beneficial in small- } \\
\text { to-medium-sized food distributors. Training; } \\
\text { size of the organization; educational attain- } \\
\text { ment and employees' workplace are the } \\
\text { most effective elements to adopt Six Sigma }\end{array}$ & $\mathrm{n} / \mathrm{a}$ & 10 & SS & A & ND & Nolink & England & $\begin{array}{c}\text { Shokri et al., } \\
2014\end{array}$ \\
\hline $\begin{array}{l}\text { Created a multi-level and a multi-objective } \\
\text { coordination optimization model for Large } \\
\text { Equipment Service-Oriented Manufacturing, } \\
\text { focusing on lean logistics objectives and the } \\
\text { relationship among quality, duration and cost }\end{array}$ & $\mathrm{n} / \mathrm{a}$ & 28 & $n / a$ & A & Inf & Link & China & $\begin{array}{c}\text { Song et al., } \\
2013\end{array}$ \\
\hline $\begin{array}{c}\text { Six sigma, quality tools and lean principles } \\
\text { were responsible for reducing the defects } \\
\text { in } 80 \% \text {, improving the customer service and } \\
\text { increasing productivity in supermarket and } \\
\text { repacking areas }\end{array}$ & Tra & 29 & $\begin{array}{l}\text { Kan, MIk, } \\
\text { TQM, SS, } \\
\text { JIT }\end{array}$ & A & Tra & Nolink & Portugal & $\begin{array}{c}\text { Sousa et al., } \\
2014\end{array}$ \\
\hline $\begin{array}{l}\text { Developed a new warehouse and distribution } \\
\text { layout, eliminating one of the bottlenecks } \\
\text { in the production process that caused late } \\
\text { delivery of the product to final customer }\end{array}$ & Tra, Time & 24 & $\begin{array}{l}5 \mathrm{~S}, \\
\text { Standz, } \\
\text { Lyt, } \\
5 \mathrm{w} 2 \mathrm{~h} \\
\end{array}$ & A & $\begin{array}{l}\operatorname{lnv}, \\
\text { Fac, Inf }\end{array}$ & Nolink & Brazil & Souza, 2015 \\
\hline $\begin{array}{l}\text { Utilized the Balanced Scorecard tool to } \\
\text { evaluate lean logistics practices in seven } \\
\text { service oriented industries. One industry was } \\
\text { classified in the first class index, four were } \\
\text { classified in the second class index, one in the } \\
\text { third class and one in the fourth class index }\end{array}$ & $\mathrm{n} / \mathrm{a}$ & ND & $\mathrm{n} / \mathrm{a}$ & $A$ & ND & Link & China & $\begin{array}{c}\text { Tong et al., } \\
2015\end{array}$ \\
\hline $\begin{array}{l}\text { The research hypotheses are empirical- } \\
\text { ly tested and supported, suggesting that } \\
\text { business process improvements need to } \\
\text { consider when operational changes can have } \\
\text { the unintended consequence of significantly } \\
\text { increasing emission of intensive transactions }\end{array}$ & $\begin{array}{l}\text { Inv, Tra, } \\
\text { SpcFac }\end{array}$ & 29 & JIT, VMI & $\mathrm{T}$ & $\begin{array}{c}\text { Tra, Inv, } \\
\text { Fac }\end{array}$ & Link & USA & $\begin{array}{l}\text { Ugarte et } \\
\text { al., } 2015\end{array}$ \\
\hline $\begin{array}{l}\text { Increases in labour discipline, cleanliness at } \\
\text { the workplace, and the growth in produc- } \\
\text { tivity of assembly workplace by approx. } 10 \\
\% \text {, through application of lean methods and } \\
\text { waste elimination }\end{array}$ & $\begin{array}{l}\text { Inv, Tra, } \\
\text { Time, } \\
\text { Know }\end{array}$ & 29 & $\begin{array}{l}\text { 5S, Visu, } \\
\text { Lyt, } \\
\text { Standz }\end{array}$ & $A$ & $\begin{array}{l}\text { Tra, } \\
\text { Fac, Inf }\end{array}$ & Link & Slovakia & $\begin{array}{l}\text { Vidová et } \\
\text { Beluský, } \\
2013\end{array}$ \\
\hline $\begin{array}{l}\text { Construction of a three-level logistic model } \\
\text { using a lean manufacturing logistics optimiza- } \\
\text { tion system and proposal of specific strate- } \\
\text { gies for optimizing logistics system }\end{array}$ & $n / a$ & $\mathrm{n} / \mathrm{a}$ & JIT & $\mathrm{T}$ & $\begin{array}{l}\text { Tra, Inv, } \\
\text { Inf, Fac }\end{array}$ & Nolink & China & Wang, 2015 \\
\hline $\begin{array}{l}\text { Proposes a multiple attribute group of } \\
\text { decision-making framework to evaluate lean } \\
\text { performance in logistics distribution centers } \\
\text { (DC). Applied it in the DC of a tobacco com- } \\
\text { mercial industry in China. }\end{array}$ & $\mathrm{n} / \mathrm{a}$ & Other & $\mathrm{n} / \mathrm{a}$ & A & ND & Nolink & China & $\begin{array}{l}\text { Wu et al., } \\
2015\end{array}$ \\
\hline
\end{tabular}




\begin{tabular}{|c|c|c|c|c|c|c|c|c|}
\hline $\begin{array}{l}\text { All respondents in a survey reported varying } \\
\text { degrees of cost savings and productivity } \\
\text { improvements with Lean and Six Sigma. } \\
\text { Large logistics companies are more likely to } \\
\text { implement Lean and SS, and the ones with } \\
\text { a higher service standard are more likely to } \\
\text { implement SS }\end{array}$ & $\mathrm{n} / \mathrm{a}$ & ND & SS & A & Tra, Inv & Nolink & $\begin{array}{l}\text { New Zea- } \\
\text { land and } \\
\text { Singapore }\end{array}$ & $\begin{array}{c}\text { Zhang et al., } \\
2016\end{array}$ \\
\hline $\begin{array}{l}\text { Identification and elimination of the main } \\
\text { waste sources culminated in productivity } \\
\text { advantages, by reducing the processes of } \\
\text { machines and minimizing production cost, } \\
\text { which increased production and improved } \\
\text { resources usage }\end{array}$ & Time & 24 & $\begin{array}{l}\text { WorkM, } \\
\text { IROG }\end{array}$ & A & Inf & Nolink & Brazil & $\begin{array}{c}\text { Zismann et. } \\
\text { al, } 2015\end{array}$ \\
\hline
\end{tabular}

Source: The author(s)' own

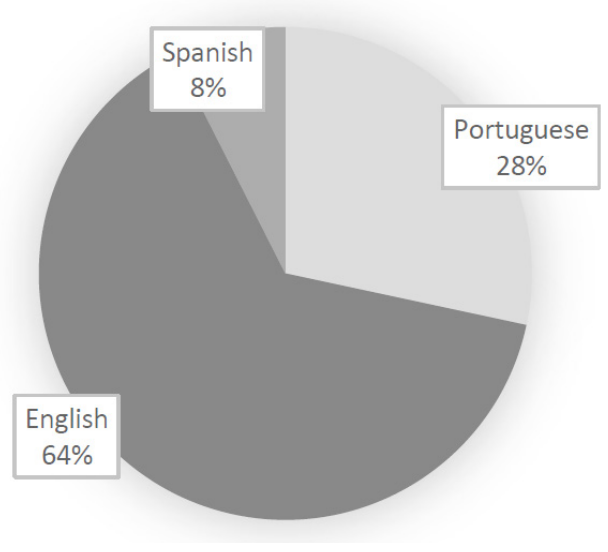

Figure 3. Classification of papers regarding their language Source: The author(s)' own

\subsection{RQ-1: In the paper's literature review, were there connection between logistics and lean thinking or six sigma concepts?}

On this matter, this analysis considered only those concepts presented in a specific section in the articles that should be dedicated for literature review. As shown in Figure 4 , most of the papers did not connect the concepts. Only 24 out of 67 effectively connected them, creating an important foundation for the lean or six sigma logistics literature. On the other hand, in 10 papers it could not be identified specific literature review sections or topics.

In general, there is little information on how the concepts relate, influence and assist each other. This is evidence of a weak theoretical basis about the combination between the ideas, which indicates lack of integration among the concepts that originated Lean or Six Sigma Logistics.

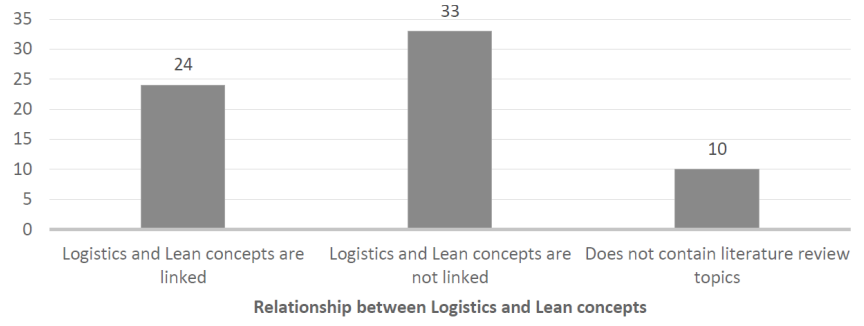

n Quantity of articles

Figure 4. Relationship between logistics and lean concepts Source: The author(s)' own

\subsection{RQ-2: Which logistics operational driver was the lean or six sigma logistics principle applied in?}

The papers were categorized in three different groups, regarding the presence of the logistics operational drives approach in them: 1 ) The paper refers to one single driver (29 papers); 2) There was a combination of two or more drivers (23 papers) and; 3 ) No driver was identified in the paper (15 papers). This classification is shown in Figure 5. The papers, in which any focus on logistics drivers was not identified, represented $22 \%$, which is an expressive amount of papers, considering the importance of logistics drivers in many aspects.

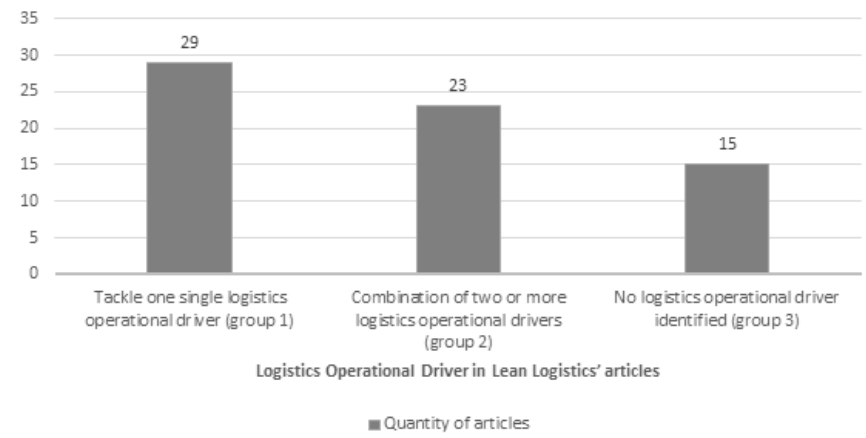

Figure 5. Operational logistics drivers in lean logistics' articles Source: The author(s)' own 
Among the papers in the second category, there was a high variation in terms of combinations of logistics drivers. The most frequent one was "Transportation and Inventory", found in 5 papers, followed by "Transportation, Inventory, Information, and Facility" and "Transportation and Facility", found in 4 papers each. It is notable that Transportation is the logistics operational driver present in more combinations, stating its importance by itself, and its impact and influence in a more holistic view is considered.

The classification of papers per logistics driver is shown in Figure 6. Transportation was the most frequent logistics driver addressed in lean or six sigma logistics, present in 32 papers, both individually and combined with others. This represents almost $50 \%$ of the sample of papers analyzed. Following Transportation, Inventory was the second driver most addressed. When it comes to the representativeness of the other logistics components, one can observe that Facility is present in 18 papers; and Information comprehended 18 papers.

The aggregation of the quantity of papers in each driver presents a large number of papers, when compared to the total considered in this review, since the combinations repeated for each driver are considered in the paper. Example, article " $A$ " was counted in Information totals' only; meanwhile article "B" was counted in both Transportation and Inventory totals.

Therefore, this analysis could describe the representativeness and approach of each logistics operational drivers in the LL or SSL context. Transportation was presented as the main logistics driver, according to the current panorama of the literature. However, it is important to emphasize that combining driver allows a more systemic and integrated view of the problem to be solved, often being the most appropriate approach, even though it is more complex. Thus, the idea of more research on LL and SSL with combined approach of logistics drivers becomes interesting.

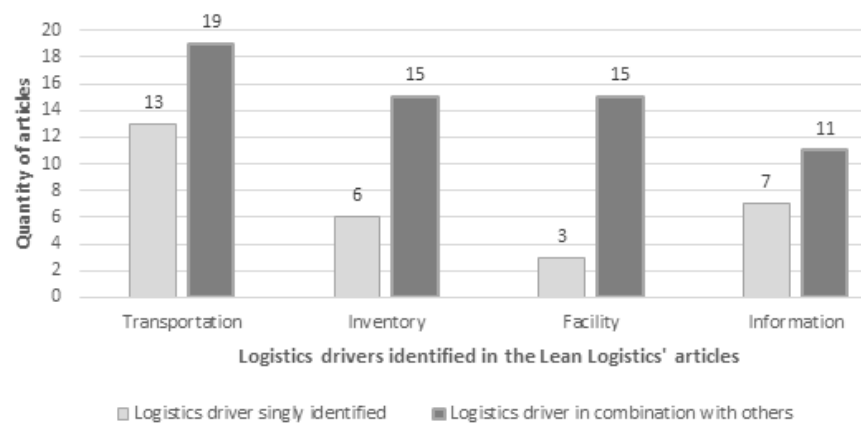

Figure 6. Quantity of papers per logistics components Source: The author(s)' own

\subsection{RQ-3: Is the paper a theoretical research or an application in some productive/industrial sector?}

The answers in RQ-3 (Figure 7) demonstrated that most of the published research is applied: 51 out of 67 papers (76\%) in the sample were essentially applied research, focusing on a specific productive or industrial sector, although, in some cases, that sector was not clearly stated. On the other hand, 16 papers (24\%) were purely theoretical research. Many of the papers applied to some sector did not have theoretical studies and were fundamentally composed of practical approaches.

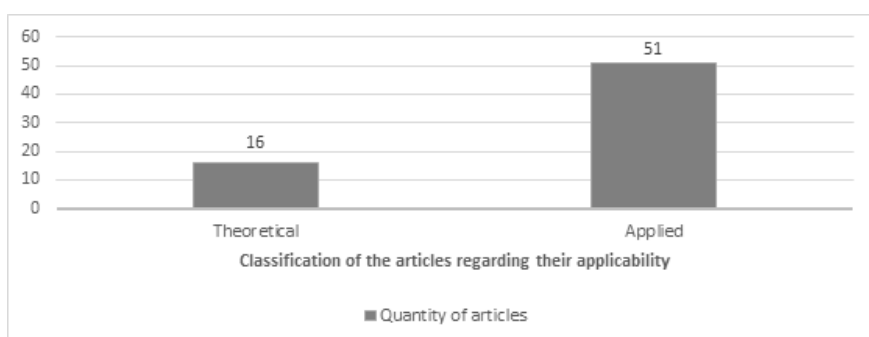

Figure 7. Classification of the papers regarding their applicability Source: The author(s)' own

There is a lack of studies and publications on LL or SSL theory. It is valid to consider that theoretical studies are an important basis for the applied studies. The fact that most publications currently focus on the application of these concepts and philosophies demonstrates a strong trend to the practical perspective of these studies.

\subsection{RQ-4: What are logistics tools and/or the principles the article addresses?}

Within the selected papers, 33 different logistics tools/ principles could be identified. The papers often addressed more than one tool at a time in their content. One can observe the distribution of papers regarding their tools in Figure 8 , containing the 12 most frequently used ones.

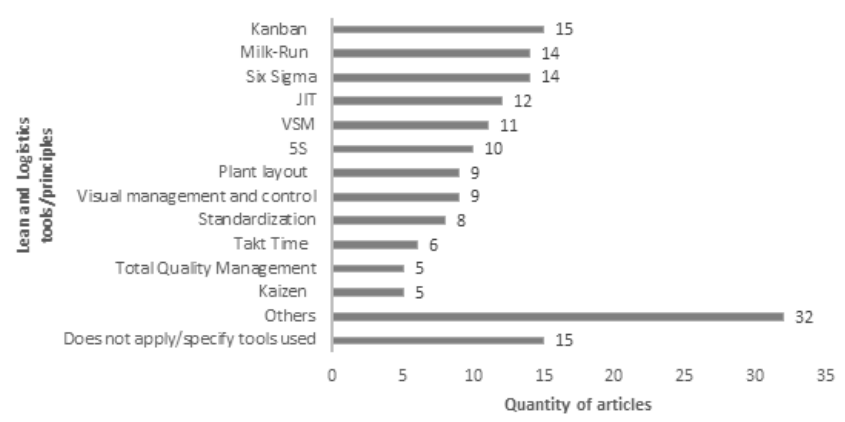

Figure 8. Lean and logistics tools broached in the articles Source: The author(s)' own 
Drazilian Journal of Operations \& Production Management Volume 14, Número 4, 2017, pp. 586-602

DOI: 10.14488/BJOPM.2017.v14.n4.a14
Kanban was the most used tool, presented in 15 papers, followed by Six Sigma and Milk-Run in 14 papers each, JIT in 12 papers, VSM (Value Stream Mapping) in 11 papers, $5 S$ in 10 papers, and so on. The predominance of Kanban among the other tools is due to its high importance in the lean thinking philosophy, which clearly has been translated to the logistics scenario as well.

It was possible to notice, however, that 15 papers did not apply or specify any tools used. This is possibly due to a lack of a clearly defined range of tools. Typically, tools originally applied in a lean or six sigma production context must be adapted in their definitions so they can be correctly applied in the logistics context, addressing its particularities.

The "Others" category aggregated the less frequently used tools: A3 Problem Solving, Overall Equipment Effectiveness (OEE), Batch size reduction, Teamwork, Total Productive Maintenance (TPM), Radio Frequency Identification (RFID), Variation Control, Spaghetti Diagram, Electronic Data Interchange (EDI), Enterprise Resource Planning (ERP), Continuous flow, Workplace Management, Global Operating Income Index (IROG), Logistics Personal Excellence, Performance Measure System, Plan for Every Part, Single Minute Exchange of Die (SMED), SIPOC, Vendor Managed Inventory (VMI), Water Spider, Constant Work in Progress, 5W2H.

\subsection{RQ-5: What is the productive/industrial/economic sector the article focuses on?}

As shown in Figure 9, the most prominent economic sector was the Automotive Industry, which accounted for $24 \%$ of all papers, followed by Metallurgical, Equipment and Machinery, Health, Food, Electronics and Air Transportation. 13 papers did not clearly define the sector of application. In the "Others" category, with 6 papers, we grouped those less representative sectors.

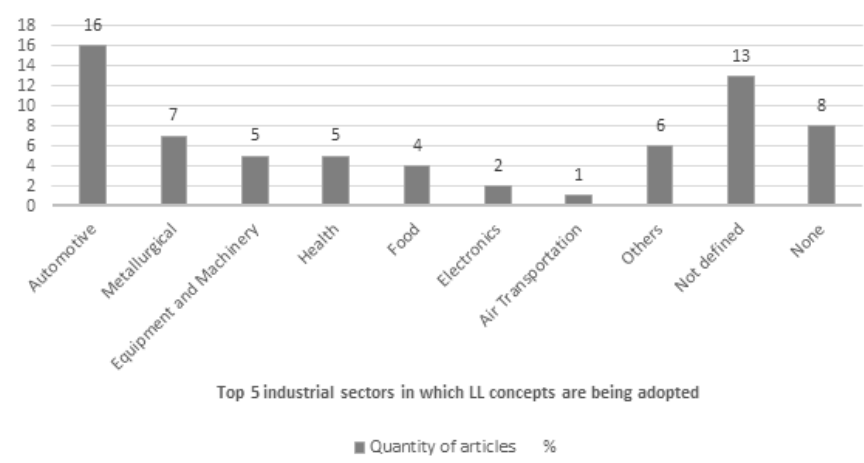

Figure 9. Top 5 industrial sectors in which LL concepts are being adopted

Source: The author(s)' own
The fact that the automotive industry was the birthplace of lean thinking, justifies the prominence of this sector. Moreover, the high absolute quantity in small gains, due to the high value added in automobiles, as well as the high competitiveness level of this sector, are strong reasons for such result. The results of this $R Q$ state the flexibility of LL and SSL application, offering application opportunities and improvements in several sectors. Therefore, there is opportunity to expand studies that address LL and SSL in different sectors, such as Metallurgical, Health, Food, Equipment and Machinery, among others.

\subsection{RQ-6: What are the wastes to be eliminated by lean or six sigma logistics addressed by the article?}

In Figure 10, the distribution of the 67 selected papers regarding wastes, agreeing with the seven wastes defined by Goldsby et Martichenko (2005), can be observe. On this matter, 47 papers considered the seven wastes approach in its analysis. However, in 20 papers it was not possible to identify which waste the paper was focused on or the waste analysis was not the paper's approach.

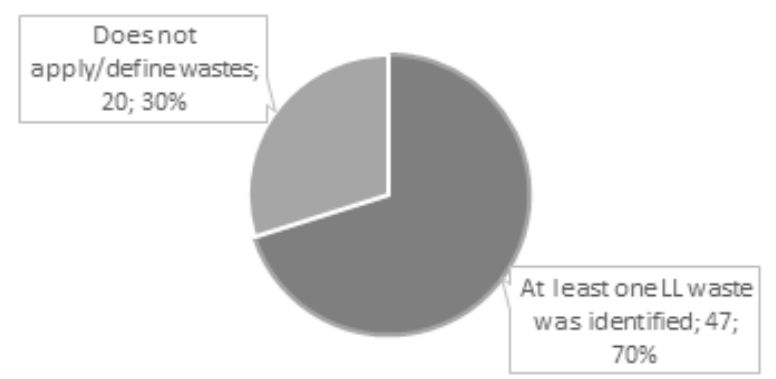

Figure 10. Distribution of papers regarding LL waste approach in their content

Source: The author(s)' own

In Figure 11, it is shown the distribution of those 47 papers in each one of the wastes: Time, Transportation, Inventory, Space and Facilities, Administration, Knowledge and Packing. Most papers addressed more than one waste at a time, i. e., combined different wastes. The waste of time was the most common, in 28 papers, followed by transportation waste, and Inventory waste. The waste caused by packing activities were the less representative, tackled in 3 papers. 


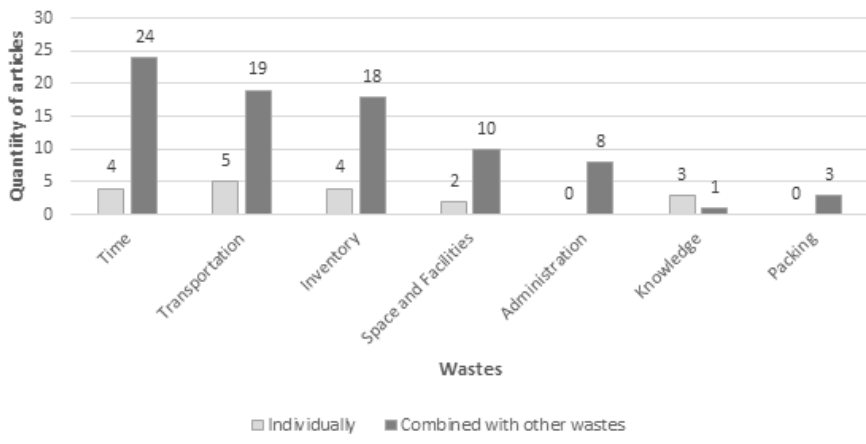

Figure 11. Papers that reduced or eliminated wastes in their LL and SSL studies

Source: The author(s)' own

\section{CONCLUSION}

The analysis of previously published research studies related to Lean and Six Sigma Logistics by means of systematic review denoted the increasing popularity of this topic in several productive and industrial sectors, as for example, in the Automotive industry, being the most frequently approached, as well as the current state of the art regarding theoretical and applied studies.

Despite its popularity in many areas, the relationship between Logistics and Lean Thinking or Six Sigma is still fragile: most papers do not link these concepts in their literature review.
Regarding the LL and SSL applications, we observed that practical applications were published in higher quantity than theoretical studies. The practical papers comprise mainly the implementation and impacts of the LL and SSL philosophy. Hence, this context generates opportunities for more theoretical contributions. This research gap is possibly due to the fragile integration - as mentioned previously - between the concepts that originates LL and SSL: Logistics and Lean Thinking; and Logistics and Six Sigma.

Regarding the tools, Kanban is presented as the most used, which is expected, since it is one of the main Lean tools. On the analysis of wastes, most of the papers referred to Motion and Waiting losses, which shows the relevance of the LL and SSL implementation for waste elimination and reduction. In Table 4, the results of each research question and their respective opportunities of research are described, based on the results analysis.

Through the analysis of the most recent researches published related to LL and SSL, following the systematic review methodology, it was possible to evaluate trends related to: productive and industrial sectors, logistics operational drivers, use of logistics tools, and elimination of wastes that motivate LL and SSL implementation. Moreover, research gaps that may provide opportunities for the development and improvement of research were identified. Therefore, future studies can be developed, following the lines proposed as opportunities, in order to contribute to the LL and SSL field.

Table 4. Achieved results and research opportunities for each research question

\begin{tabular}{|c|c|c|}
\hline ID & Results & Opportunities \\
\hline RQ-1 & $\begin{array}{l}\text { Relationship between theoretical concepts of Logistics and } \\
\text { Lean Thinking or Six Sigma is still fragile, since they were } \\
\text { often approached separately in the papers' literature review. }\end{array}$ & $\begin{array}{l}\text { Research that effectively relate the concepts of Logistics and Lean } \\
\text { Thinking or Six Sigma, enabling the construction of new knowl- } \\
\text { edge about LL and SSL, linking the topics in an integrated way. }\end{array}$ \\
\hline RQ-2 & $\begin{array}{l}\text { Among the logistics operational drivers considered, } \\
\text { Transportation was approached in most of papers, both } \\
\text { individually or combined with other drivers. }\end{array}$ & $\begin{array}{l}\text { Theoretical and practical studies directed to identify and apply LL } \\
\text { and SSL principles and concepts in other logistics drivers (Inven- } \\
\text { tory, Facility and Information), individually or, specially, combined } \\
\text { (integrated) with each other, including Transportation. }\end{array}$ \\
\hline RQ-3 & $\begin{array}{c}\text { The majority of LL and SSL publications were applied stud- } \\
\text { ies (not theoretical studies), considering the implementa- } \\
\text { tion of the Lean or Six Sigma Philosophy. }\end{array}$ & $\begin{array}{l}\text { Theoretical studies on LL and SSL and their applicability in differ- } \\
\text { ent sectors or contexts, considering possible adaptations and the } \\
\text { major error risks already made in order to prevent them. }\end{array}$ \\
\hline RQ-4 & $\begin{array}{c}\text { The main tools used were: Kanban, Milk Run and combina- } \\
\text { tion of Six Sigma methods; there was no clear definition in } \\
\text { terms of which tools are also LL and SSL tools. }\end{array}$ & $\begin{array}{l}\text { Application of less widely used Lean tools; Studies that define } \\
\text { the range of LL and SSL tools, considering both logistics and } \\
\text { Lean or Six Sigma tools, with their respective adaptations }\end{array}$ \\
\hline RQ-5 & $\begin{array}{c}\text { The automotive sector was scenario for most LL and SSL } \\
\text { applications, demonstrating that other industries still have } \\
\text { a certain lack of applications in this sense. }\end{array}$ & $\begin{array}{l}\text { Studies and research applied to other productive and industri- } \\
\text { al sectors, for example, in healthcare, disseminating Lean } \\
\text { Healthcare ideas within a logistic context. }\end{array}$ \\
\hline RQ-6 & $\begin{array}{c}\text { Many publications have not defined or mentioned the } \\
\text { wastes considered in the productive systems under study. } \\
\text { Moreover, time was the main type of waste identified and } \\
\text { eliminated, while waste of packing, knowledge and admin- } \\
\text { istration were the less identified ones. }\end{array}$ & $\begin{array}{l}\text { Studies and research that clearly address the wastes of the } \\
\text { lean philosophy and six sigma in the logistic context, as well } \\
\text { as its importance, providing a dense theoretical basis on such } \\
\text { wastes, so that the process of identifying wastes in practical } \\
\text { contexts can be simplified. }\end{array}$ \\
\hline
\end{tabular}


Brazilian Journal of Operations \& Production Management

Volume 14, Número 4, 2017, pp. 586-602

DOI: 10.14488/BJOPM.2017.v14.n4.a14

\section{REFERENCES}

Adolph, S. et al. (2016), "Overall Commissioning Effectiveness: Systematic Identification of Value-added Shares in Material Supply", Proceedings of the 48th CIRP: Conference on Manufacturing Systems. Vol.41, pp. 562-567.

Aguilar-Escobar, V. G. et al. (2013), "Mejorando la Cadena de Suministro de un Hospital Mediante la Gestión Lean", Revista de Calidad Asistencial, v.28, n.6, pp. 337-344.

Aguilar-Escobar, V. G.; Garrido-Vega, P. (2013), "Gestion Lean em Logística de Hospitales: Estúdio de un Caso". Revista de Calidad Asistencial. Vol.28, n.1. pp. 42-49.

Almeida Filho, J. F.; Lobosco, A. (2015), "A Filosofia Lean Manufacturing Aplicada ao Transporte de Cargas Aéreas. Um Estudo na Empresa TAM Cargo", IV SINGEP: International Symposium on Project Management, Innovation and Sustainability, available at: www.singep.submissao.com.br/4singep/ resultado/default.asp, (Accessed on 22 december 2016).

Alnahhal, M., et al. (2014), "In-plant Milk Run Decision Problems". Presented at GOI 2014: International Conference on Logistics and Operations Management, Rabat, Marocco, 5-7 June 2014.

Al-Qatawneh, L. et al. (2013), "Reducing Stock-out Incidents at a Hospital Using Six Sigma". International Journal of Social, Behavioral, Educational, Economic, Business and Industrial Engineering. v.7, No.5, pp. 1166-1173, available at: www.waset.org/journal/Social (Accessed on 22 December 2016).

Alves, J. A.; Santos, A. P. (2013), "Logística Lean para Redução dos Efeitos da Variação da Demanda no Abastecimento de Linhas de Produção", Perspectivas Contemporâneas. v.8, n.1, pp. 53-66.

Ángeles, F. E. T. (2013), "Six Sigma en Logística: Aplicación en el Almacén de una Unidad Minera", Revista de la Facultad de Ingeniería Industrial. v.16, n.2, pp. 67-74.

Antunes, D. L. et al. (2013), "Using Project Six Sigma and Lean Concepts in Internal Logistics", Proceedings of the World Congress on Engineering, London, Vol.1.

Bagheri, O. et al. (2016), "Implementation of milk run logistics in vehicle cooling system of pride Kia parts", Journal of Fundamental and Applied Sciences, Vol. 8, No.3S, pp. 23072325, available at: www.jfas.info/index.php/jfas/article/ view/1304 (Accessed on 13 November 2016).

Bednár, R. et al. (2012a), "Lean Principles Application in Business Logistics". Metal. Vol.25, No.5.

Bednár, R. et al. (2013b), "Implementation Procedure of Lean Methods in Logistics Processes". Metal. Vol.17, No.5.

Belli, F. (2012), “Logística Lean como Diferencial Competitivo para o Setor Metalúrgico". E-Tech: Tecnologias para Competitividade Industrial. p. 129-144.
Benevides, G. et al. (2013), "A eficiência da gestão de estoques: estudo sobre a aplicação do lean manufacturing". Revista de Tecnologia Aplicada (RTA). Vol.2, No.2, pp. 19-33.

Blöchl, S. J.; Schneider, M. (2016), "Simulation Game for Intelligent Production Logistics - The PuLL ${ }^{\circledR}$ Learning Factory". 6th Conference on Learning Factories. v. 54. pp. 130-135.

Carreira, M. L.; Sobrinho, P. B. (2012) “Aplicação de ferramentas da produção enxuta na logística interna: Estudo de Caso. Revista de Ciências Gerenciais. Vol.16. No.24. pp. 51-75.

Carvalho, M. S. et al. (2016), "Definition of a Collaborative Working Model to the Logistics Area using Design for Six Sigma", International Journal of Quality and Reliability Management. Vol.33, No.4, pp. 465-475.

Catapan, A. et al. (2013), "Lean Manufacturing: um Estudo de Caso da dua Aplicação em Empresa do Ramo de Metais Sanitários", Connexio: Revista Científica da Escola de Gestão e Negócios, Vol.3, No.1, pp. 95-112, available at: www.repositorio.unp.br/index.php/connexio/article/view/514 (Accessed on 18 December 2016).

Celis, O. L. M.; García, J. M. S. (2012), “Modelo Tecnológico para el Desarrollo de Proyectos Logísticos Usando Lean Six Sigma", Estudos Gerenciales - Journal of Management and Economics for Iberoamerica, Vol.28, No.124, pp. 24-43.

Costa, T. H. G.; Costa, S. E. G. (2016), “Aplicação de ferramentas Lean para melhoria do sistema de movimentação interna de materiais em uma planta da indústria automobilística". Journal of Lean Systems. Vol.1, No.2. pp. 90-106.

Dennis, P. (2008), Produção Lean Simplificada: um guia para entender o sistema de produção mais poderoso do mundo, 2 ed., Bookman, Porto Alegre, RS.

Domingos, B. S. M et al. (2013), "Processo de Redução e Reorganização de Estoque Kanban em uma Indústria de Máquinas e Equipamentos: Estudo de Caso". 7th COBEF: Brazilian Congress in Manufacturing Engineering.

Dornhofer, M. et al. (2016), "Logistics Performance Measurement System for the Automotive Industry". Logistics Research. Vol.9, No.11.

Ferreira, R. U. et al. (2014), "Aprendizagem por projeto: aplicação do lean logística na rotina dos trabalhadores em uma empresa do Noroeste Paulista", XIII INTERTECH: International Conference on Engineering and Technology Education. Vol.13, pp.16-19, available at: http://copec.eu/intertech2014/ (accessed on 20 December 2016).

Ferreira, R. U.; Magno, C. O. V. (2013), “Logística Enxuta: Distribuição com Base na Técnica Lean Thinking", Proceedings of WCSEIT: World Congress on Systems Engineering and Information Technology, Portugal, 17-20 November 2013, Vol.1, pp. 126-130, available at: www.copec.eu/congresses/wcseit2013/ (accessed on 20 December 2016). 
Garza-Reyes, J. et al. (2016), "Lean and Green in the Transport and Logistics Sector - A Case Study of Simultaneous Deployment", Production Planning \& Control. Vol.27, No.15, p. 1221-1232.

Goldsby, T.; Martichenko, R. (2005), Lean Six Sigma Logistics: Strategic Development to Operational Ssuccess. 1 ed., J. Ross Publishing, Florida.

Gonçales Filho, M. et al. (2014), "Logística, cadeia de suprimentos e pensamento enxuto nas organizações: Uma análise bibliométrica", Espacios, v. 35, n. 13, pp. 13.

Gutierrez-Gutierrez, L. et al. (2016), "Logistics Services and Lean Six Sigma Implementation: a Case Study", International Journal of Lean Six Sigma, Vol.7, No.3, pp. 324-342.

Haan, J. et al. (2012), "Creative tension in a lean work environment: Implications for logistics firms and workers", International Journal of Production Economics. Vol.137, No.1, pp. 157-164.

IBGE - Instituto Brasileiro de Geografia e Estatística. (2017), CONCLA: Comissão Nacional de Classificação. Available at: www.concla.ibge.gov.br/busca-online-cnae.html. Accessed on 20 July 2017.

Jager, A. et al. (2014), "LOPEC - Logistics Personal Excellence by Continuous Self-Assessment". Proceedings of the 8th DET: International Conference on Digital Enterprise Technology. Vol.25, pp. 69-74.

Kach, S. C. et al. (2015), “Estudo de caso na implementação do kanban em uma indústria de componentes plásticos rotomoldados", Revista Eletrônica de Tecnologia e Cultura. Vol.16.

Khorasani, S. T. et al. (2015), "A structured review of lean supply chain management in health care, paper presented at ASEM 2015: American Society for Engineering Management, Indiana, available at: www.asem.org/ (Accessed on 12 December 2016).

Khoury, S. et al. (2013), “Logistics Managers' Views of Six Sigma Integration within Logistics Operations", International Journal of Applied Decision Sciences. Vol.6, No.1, pp. 35-49.

Kilic, H. S. et al. (2012), "Classification and modeling for in-plant milk-run distribution systems", International Journal of Advanced Manufacturing Technology. Vol.62, No.9-12, pp. 1135-1146.

Klenk, E. et al. (2015), “Operating Strategies for In-Plant Milk-Run Systems", IFAC-Papers Online. Vol.38, No.3, pp. 1882-1887.

Korytkowski, P.; Karkoszka, R. (2016), "Simulation-Based Efficiency Analysis of an In-Plant Milk-Run Operator under Disturbances", International Journal of Advanced Manufacturing and Technology. Vol.82. pp. 827-837.

Kravenkit, S.; Arch-Int, S. (2013), "The Improvement of Logistic Management using Lean and RFID Technology", pre- sented at 3rd ICISA: International Conference on Information Science and Applications, Suwon, South Korea, 24-26 June 2013, Available at: http://icatse.org/icisa/, accessed on 20 December 2017.

Kubasáková, I.; Poliaková, B. (2014), "Lean Distribution Framework". Transport I Informatyka. Vol.4, No.1, pp. 117-123.

Lee, K. et al. (2013), "Using LSS to Improve the Efficiency and Quality of a Refund Process in a Logistics Center", International Journal of Lean Six Sigma. Vol.4, No.4, pp. 409-424.

Lent, W. A. et al. (2012), "Exploring improvements in patient logistics in Dutch hospitals with a survey", BMC Health Services Research. Vol.12.

Li, F. et al. (2014), "Applications of Lean Logistics on Engine Manufacturing Planning", SAE International Journal of Materials and Manufacturing. Vol.7, No.2, pp.308-312.

Li, H. et al. (2015), "The Evaluation of Lean Logistics Performance Based Rough Sets and Grey Theory", Proceedings of the 6th International Asia Conference on Industrial Engineering and Management Innovation, pp. 349-357.

Liang, D.; Wang, H. (2013), "Study on the Development Strategy of Lean Logistics for Automobile Enterprises under Green Supply Chain Environment", Applied Mechanics and Materials. Vol.397-400. pp. 2677-2680.

Liker, J. K. (2005), O Modelo Toyota: 14 princípios de gestão do maior fabricante do mundo, 1 ed., Bookman, Porto Alegre, RS.

Loos, M. J.; Rodriguez, C. M. T. (2015), “Mapeamento do Estado da Arte do Tema Avaliação de Desempenho Direcionado para a Logística Lean", Espacios. Vol.36, No.14, pp. 7.

Marodin, G. A et al. (2012), "Avançando na implantação da logística interna lean: dificuldades e resultados alcançados no caso de uma empresa montadora de veículos", Produção Online. Vol.12. No.2. pp. 455-479, available at: www. producaoonline.org.br/rpo/article/view/932 (accessed on 3 January 2017).

Marques, A. F. et al. (2013), “An approach for integrated design of flexible production systems". Forty Sixth CIRP Conference on Manufacturing Systems, Vol.7, pp. 586-591.

Mehrsai, A. et al. (2014), "Bridging lean to agile production logistics using autonomous carriers in pull flow", International Journal of Production Research, Vol.52, No.16, pp. 4711-4730.

Mulholland, K.; Stewart, P. (2014), "Workers in Food Distribution: Global Commodity Chains and Lean Logistics", New Political Economy, Vol. 19, No. 4, pp. 534-558.

Muller, E. et al. (2014), A method to generate energy value-streams in production and logistics in respect of timeand energy- consumption. Production Management. Vol.8, pp.243-251. 
Negrão, L. L. L. et al. (2016), “Lean practices and their effect on performance: a literature review", Production Planning \& Control. Vol.28 No.1, pp.33-56.

Nogueira Neto, M. S. et al. (2016), “Um Estudo de Caso com Aplicação do Kaizen em uma Empresa de Produtos Cirúrgicos", Espacios, Vol. 37, No. 19.

Onyemechi, C. (2013), "Logistics Centres Assessed as a Port City Decongesting Strategy: Case Study of a Nigerian Port City", Journal of Maritime Research. Vol. 10, No. 1, pp. 39-42.

Patel, D.; Patel, M. B. (2013), “Design and development of an internal milk-run material supply system in automotive industry", International Journal of Application of Innovation in Engineering and Management. Vol. 2, No. 8, pp. 233-235.

Pinto, R. A. Q. et al. (2013), "Inventory management and lean manufacturing: a case study in a metallurgical company", RAD: Revista Administração em Diálogo, Vol.15, No.1, pp. 111-138.

Qu, T. et al. (2012), "RFID-Enabled Just-in-Time Logistics Management System for 'SHIP' - Supply Hub in Industrial Park", SUN Conferences: Computers and Industrial Engineering, Vol. 42, available at: www.conferences.sun.ac.za/index. php/cie/cie-42/paper/view/263 (accessed on 20 December 2016).

Rocha, E. et al. (2013), "Analisando as implicações da logística enxuta à luz da interface entre clientes e fornecedores", Espacios, Vol. 34 No.5, pp. 17.

Sá, H. S. et al. (2014), "Nationalization of Suppliers in an Automobile Industry", Engineering Research: Technical Reports. Vol. 5, No. 1.

Sadraoui, T.; Fayza, J. (2014), “Efficacité de la Méthologie Six Sigma dans la Gestion de la Chaine Logistique", International Journal of Econometrics and Financial Management, Vol.2, No.6, pp. 220-235.

Satoglu, S. I.; Sahin, I. E. (2013), “Design of a just-in-time periodic material supply system for the assembly lines and an application in electronics industry", International Journal of Advanced Manufacturing and Technology, Vol. 65. pp. 319332.

Shokri, A. et al. (2014), "Evaluating Six Sigma methodology to improve logistical measures of food distribution SMEs", Journal of Manufacturing Technology Management, Vol. 25, No. 7, pp. 998-1027.
Song, Z. Y. et al. (2013), "Collaborative Optimization of Planning and Control for Large Equipment Service-oriented Manufacturing Based on Lean Logistics", Information Technology Journal. Vol. 12, No. 24, pp. 8249-8255.

Sousa, S. et al. (2014), "Lean Six Sigma in internal logistics: A case study", IAENG Transactions on Engineering Sciences, pp. 161-170.

Souza, J. A. (2015) "Lean Logistics: Uma Abordagem Enxuta na Logística Industrial de uma Empresa Metal Mecânica”, Revista Científica Tecnológica, Vol. 3, No. 2, pp. 174-195.

Tong, L. et al. (2015), "The Evaluation of Lean Logistics Performance Based on Balanced Score Card and Unascertained Sets", Proceedings of LISS: International Conference on Logistics, Informatics and Service Sciences.

Ugarte, G. M. et al. (2015), “Lean versus Green: The Impact of Lean Logistics on Greenhouse Gas Emissions in Consumer Goods Supply Chains", Journal of Purchasing \& Supply Management, Vol. 22, No.2, pp. 89-109.

Vidová, H.; Beluský, M. (2013), "The Application of Selected Lean Methods for Waste Removal in Logistics of Slovak Industrial Plants", Applied Mechanics and Materials, Vol. 309. pp. 286-293.

Wang, X. (2015), “Optimization Study Based on Lean Logistics in Manufacturing Enterprises", Proceedings of China Modern Logistics Engineering. Vol. 286, pp. 463-471.

Wu, W. et al. (2015), "A multiple attribute group decision making framework for the evaluation of lean practices at logistics distribution centers", Annals of Operations Research. Vol.247. No.2. pp. 735-757.

Zhang, A. et al. (2016), "Lean and Six Sigma in Logistics: a Pilot Survey Study in Singapore", International Journal of Operations \& Production Management, Vol.36, No.11. pp. 16251643.

Zismann, D. et al. (2015), "O Desempenho do Processo de Corte a Laser Através de Práticas Enxutas no Ramo Metal-Mecânico", Iberoamerican Journal of Project Management, Vol. 6, No. 2, pp. 52-76.

Zylstra, K. D. (2008), Distribuição Lean: a abordagem enxuta aplicada à distribuição, logística e cadeia de suprimentos. Bookman, Porto Alegre, RS. 